\title{
Peran Penggunaan Sistem Informasi Akuntansi pada Usaha Kecil Se- Jabodetabek dengan Ketidakpastian Lingkungan sebagai Pemoderasi
}

\author{
Shirlyani ${ }^{1}$, Syahril Djaddang ${ }^{2}$, Darmansyah ${ }^{3}$ \\ ${ }^{1.2 .3}$ Universitas Pancasila, Jl. Srengseng Sawah, Jagakarsa, Jakarta Selatan, 12640
}

INFO ARTIKEL

JEL Classsification:

M41

D83

Keywords:

education,

business scale,

accounting training,

environmental

uncertainty,

use of information

systems accounting

\section{ABSTRACT}

This study aims to determine the role of the use of accounting information systems in Small and Medium Enterprises (SMEs) throughout Jabodetabek with environmental uncertainty as moderating. The sample in this study were 101 respondents. The results showed that the education of SME owners influenced the use of accounting information systems in SMEs as well as when moderated by environmental uncertainty, education of SME owners influenced the use of accounting information systems in SMEs. The scale of business influences the use of accounting information systems in SMEs, including when moderated by environmental uncertainty, the scale of business influences the use of accounting information systems in SMEs. Accounting training does not affect the use of accounting information systems in SMEs and when moderated by environmental uncertainty, accounting training does not affect the use of accounting information systems in SMEs.

\begin{abstract}
ABSTRAK
Penelitian ini bertujuan untuk mengetahui peran penggunaan sistem informasi akuntansi pada Usaha Kecil dan Menengah (UKM) Se-Jabodetabek dengan ketidakpastian lingkungan sebagai pemoderasi. Sampel dalam penelitian ini adalah 101 responden. Hasil penelitian menunjukkan bahwa pendidikan pemilik UKM berpengaruh terhadap penggunaan sistem informasi akuntansi pada UKM begitu pula ketika dimoderasi oleh ketidakpastian lingkungan, pendidikan pemilik UKM berpengaruh terhadap penggunaan sistem informasi akuntansi pada UKM. Skala usaha berpengaruh terhadap penggunaan sistem informasi akuntansi pada UKM termasuk ketika dimoderasi oleh ketidakpastian lingkungan, skala usaha berpengaruh terhadap penggunaan sistem informasi akuntansi pada UKM. Pelatihan akuntansi tidak berpengaruh terhadap penggunaan sistem informasi akuntansi pada UKM serta ketika dimoderasi oleh ketidakpastian lingkungan, pelatihan akuntansi tidak berpengaruh terhadap penggunaan sistem informasi akuntansi pada UKM.
\end{abstract}




\section{Pendahuluan}

UKM terbukti tahan terhadap krisis dan mampu survive, pertama, tidak memiliki utang luar negeri. Kedua, tidak banyak utang ke perbankan karena mereka dianggap unbankable. Ketiga, menggunakan input lokal. Keempat, berorientasi ekspor (Kuncoro, 2008). Perlambatan pertumbuhan ekonomi dunia, selain menyebabkan volume perdagangan global pada tahun 2009 merosot tajam, juga akan berdampak pada banyaknya industri besar yang terancam bangkrut, terjadinya penurunan kapasitas produksi, dan terjadinya lonjokkan jumlah pengangguran dunia. Bagi negara-negara berkembang dan emerging markets, situasi ini dapat merusak fundamental perekonomian, dan memicu terjadinya krisis ekonomi.

Adanya perlambatan pertumbuhan ekonomi tersebut, maka usaha kecil memegang peran yang besar apabila dikaitkan dengan masalahmasalah ekonomi dan sosial dalam negeri seperti tingginya tingkat kemiskinan, besarnya jumlah pengangguran, ketimpangan distribusi pendapatan, proses pembangunan yang tidak merata, dan masih banyak lagi. Besarnya peranan usaha kecil dalam perekonomian nasional dilihat dari Industri usaha kecil dalam perekonomian Indonesia yang saat ini menjadi semakin penting terutama setelah krisis melanda ekonomi di Indonesia. Para pengusaha kecil pada saat krisis ekonomi dipandang telah menunjukkan kekuatan dan potensi sesungguhnya dalam hal daya tahan menghadapi guncangan maupun dalam hal peranannya sebagai salah satu motor penggerak ekonomi nasional. (Trianti, 2013)

Teknologi informasi dikatakan dapat membantu Usaha Kecil dan Menengah dalam menyediakan infrastruktur yang diperlukan untuk menyediakan informasi yang tepat bagi penggunanya (Ghobakhloo et al., 2012). Ismail dan King (2007), mengatakan perusahaan yang memiliki kecanggihan teknologi memiliki tingkat keselarasan sistem informasi akuntansi yang baik dibandingkan dengan yang tidak menggunakan. Pemakaian sistem informasi oleh seluruh anggota merupakan salah satu pengukur kesuksesan pengembangan sistem informasi pada organisasi yang bersangkutan. Kebutuhan akan informasi yang cepat, andal, dan akurat dalam kondisi lingkungan yang penuh dengan ketidakpastian mutlak diperlukan. Kebutuhan tersebut dapat dipenuhi jika perusahaan melakukan investasi dibidang teknologi informasi.

Permasalahan UMKM yang berkaitan dengan sumber daya manusia (human resources), manajemen, funding access, informasi teknologi dan market access membuat para UMKM umumnya memposisikan diri untuk "apatis" dalam membangun simbiosis yang harmonis dengan pihak intermediary. Salah satu upaya yang dapat diusung dan dikembangkan Deputi Bidang Pengkajian Sumber daya UKMK Kementerian Negara Koperasi dan UKM pada tahun 2008 yang lalu telah menyusun pedoman pengambilan keputusan pengembangan investasi UMKM berbasis teknologi dan sistem informasi, yaitu Decision Support System (DSS) yang menjembatani permasalahan dasar UMKM dan kebutuhan pihak intermediary swasta untuk meningkatkan portofolio investasinya (Deputi Bidang Pengkajian Sumber Data UKMK, 2010).

Grande (2011) menyatakan bahwa Sistem Informasi Akuntansi (SIA) adalah suatu alat yang termasuk ke dalam bidang Teknologi Informasi dan Sistem, yang dirancang untuk membantu dalam pengolahan dan pengendalian topik yang terkait dalam bidang ekonomi keuangan perusahaan. Sistem informasi akuntansi memberi kesempatan bagi pebisnis untuk meningkatkan efisiensi dan efektivitas dalam pengambilan keputusan sehingga memungkinkan perusahaan memperoleh keunggulan kompetitif (Edison et al., 2012).

UKM di Indonesia dengan segala keterbatasannya dapat berkembang dengan memanfaatkan teknologi informasi, perlu 
dukungan berupa pelatihan dan penyediaan fasilitas. Sebagian besar UKM berlokasi di desa-desa dan kota-kota kecamatan, serta belum mampu untuk memiliki jaringan internet sendiri. Pada dasarnya dengan bantuan teknologi informasi dan komunikasi dapat meningkatkan kinerja sehingga lebih efektif dan efisien. Dengan teknologi informasi, UKM akan lebih siap untuk bersaing tidak hanya di dalam negeri tetapi juga dengan produk-produk luar negeri.

Usaha Kecil dan Menengah (UKM) mempunyai kontribusi yang cukup besar dalam pertumbuhan ekonomi di Indonesia. Semakin besar kontribusi Usaha Kecil dan Menengah (UKM) semakin kuat ekonomi negara tersebut (Astuti dan Widiatmoko, 2003). Oleh karena itu, pemerintah hendaknya fokus pada sektor Usaha Kecil dan Menengah (UKM) sebagaimana dapat dilihat dari perannya dalam pertumbuhan ekonomi nasional seperti produk domestik bruto (PDB) yang diciptakan serta penyerapan tenaga kerja. Sementara itu, dalam perekonomian global saat ini, Usaha Kecil dan Menengah (UKM) dituntut untuk melakukan perubahan guna meningkatkan daya saingnya.

\section{Perkembangan Data Usaha Mikro, Kecil, Menengah (UMKM) dan Usaha Besar (UB)}

\begin{tabular}{lcrr}
\multicolumn{1}{c}{ Indikator } & Satuan & \multicolumn{2}{c}{ Jumlah } \\
& & Tahun 2014 & \multicolumn{1}{c}{ Tahun 2015 } \\
\hline $\begin{array}{l}\text { A. Usaha Mikro, Kecil dan Menengah } \\
\text { (UMKM) }\end{array}$ & (Unit) & 57.895 .721 & 59.262 .772 \\
- Usaha Mikro (UMi) & (Unit) & 57.189 .393 & 58.521 .987 \\
- Usaha Kecil (UK) & (Unit) & 654.222 & 681.522 \\
- Usaha Menengah (UM) & (Unit) & 52.106 & 59.263 \\
B. Usaha Besar (UB) & (Unit) & 5.066 & 4.987 \\
\hline
\end{tabular}

Sumber : Kementerian Koperasi dan Usaha Kecil dan Menengah yang diolah dari data Badan Pusat Statistik (BPS) 2015

Pemerintah membina Usaha Kecil dan Menengah melalui Dinas Koperasi dan Usaha Kecil Menengah (UKM), masing-masing provinsi atau kabupaten bahkan kota. Namun, kenyataannya Usaha Kecil dan Menengah di Indonesia tidak berjalan dengan baik, banyak kendala salah satunya yaitu pengusaha tidak mengetahui berapa keuntungan bersih usahanya. Dari kendala pengetahuan keuangan tersebut maka dibutuhkan teknologi informasi untuk membantu memajukan Usaha Kecil dan Menengah ke depannya. Menghadapi kemajuan teknologi informasi yang semakin berkembang mempunyai dampak dalam dunia bisnis. Ketidakmampuan menyediakan dan menggunakan informasi akuntansi merupakan faktor utama yang menimbulkan permasalahan dan mengakibatkan kegagalan perusahaan kecil dan menengah dalam pengembangan usaha (Astuti, 2007).

Beberapa penelitian telah dilakukan untuk memverifikasi tentang penggunaan sistem informasi. Uji empiris yang dilakukan oleh Solovida (2010), membuktikan pendidikan pemilik berpengaruh signifikan terhadap penyiapan dan penggunaan informasi akuntansi sedangkan Hariyadi (2013) yang menyatakan bahwa pendidikan pemilik tidak berpengaruh signifikan terhadap penggunaan informasi akuntansi.

Widiyanti (2013) menyatakan bahwa skala usaha tidak berpengaruh signifikan terhadap penggunaan informasi akuntansi keuangan. Demikian halnya dengan penelitian Rahman (2016), membuktikan bahwa pelatihan akuntansi yang pernah diikuti manajer (pemilik) 
dapat berpengaruh terhadap penyediaan dan penggunaan informasi akuntansi.

Setyaningrum, Wiratno, dan Sukirman (2014) yang menunjukkan bahwa ketidakpastian lingkungan memoderasi pengaruh pendidikan pemilik usaha, pengetahuan akuntansi, budaya perusahaan, dan umur usaha terhadap informasi akuntansi.

Penelitian ini berbeda dengan penelitian terdahulu pada penelitian ini dilakukan pada Usaha Kecil dan Menengah Se-Jabodetabek, jumlah sampel, dalam penelitian ini menambahkan satu variabel moderasi yaitu ketidakpastian lingkungan, adapun alasan penulis menambah satu variabel adalah untuk membuktikan apakah faktor pendidikan pemilik UKM, skala usaha, dan pelatihan akuntansi berpengaruh terhadap penggunaan sistem informasi akuntansi.

\section{Telaah Teori dan Pengembangan Hipotesis}

Theory of Reason Action (TRA) yang dikembangkan oleh Ajzen dan Fishbein (1980) adalah suatu teori yang berhubungan dengan sikap dan perilaku individu dalam melaksanakan kegiatan atau tindakan yang beralasan dalam konteks penggunaan teknologi informasi. Seseorang akan memanfaatkan teknologi informasi atau sistem informasi dengan alasan bahwa teknologi atau sistem tersebut akan menghasilkan manfaat bagi dirinya. Perilaku pemakai sistem bersamaan dengan norma sosial dan faktor situasional lainnya memotivasi ke niat atau minat untuk memanfaatkan sistem informasi dan pada akhirnya meningkatkan penggunaan sistem informasi tersebut.

Spilker (1995) mengemukakan bahwa motivasi untuk mempelajari tentang pengetahuan akuntansi akan meningkatkan pemahaman manajer atau pemilik dalam menerapkan akuntansi dalam perusahaan. Sehingga dapat disimpulkan bahwa semakin baik pengetahuan akuntansi yang dimiliki oleh pemilik usaha, maka makin baik pula kemampuan mereka dalam hal penggunaan informasi akuntansi dalam praktik usahanya. Penggunaan informasi akuntansi dalam suatu usaha atau bisnis akan selalu dipengaruhi oleh motivasi pelaku usaha atau bisnis dalam menjalankan kegiatan usahanya.

Rahutami (2009) menyatakan bahwa motivasi secara umum timbul ketika pelaku kegiatan mengetahui kebutuhan dan kekurangannya, kemudian mencari cara untuk memuaskan kebutuhannya itu. Perilaku kegiatan tersebut akan diarahkan pada tujuan yang diharapkan, sehingga akan berpengaruh pada kinerjanya. Kemudian pelaku bisnis akan menilai kembali kebutuhannya setelah melihat hasil yang diperoleh dari kinerja yang dilakukan. Penggunaan informasi akuntansi akan meningkat karena pemilik usaha mengetahui kebutuhan informasi tersebut dalam pengambilan keputusan bisnis.

Menurut Duncan (1972) ketidakpastian lingkungan merupakan keterbatasan individu dalam menilai probabilitas gagal atau berhasil keputusan yang dibuat. Bagi suatu organisasi, sumber utama ketidakpastian berasal dari lingkungan, yang meliputi persaingan, konsumen, pemasok, regulator, dan teknologi yang dibutuhkan (Govindarajan, 1986). Individu akan mengalami ketidakpastian lingkungan yang tinggi jika merasa lingkungan tidak dapat diprediksikan dan tidak dapat memahami bagaimana komponen lingkungan akan berubah (Milliken, 1987). Sedangkan dalam ketidakpastian lingkungan yang rendah (lingkungan relatif stabil), individu dapat memprediksi keadaan di masa datang sehingga langkah-langkah yang akan dilakukannya dapat direncanakan dengan lebih akurat (Duncan, 1972).

Romney dan Steinbart (2010) menjelaskan sistem informasi akuntansi adalah suatu sistem yang menyajikan pengguna dengan data yang diolah dan transaksi yang mereka butuhkan untuk mengendalikan, mengoperasikan, dan rencana bisnis. Sistem Informasi Akuntansi 
(SIA) membantu perusahaan dan tim manajemen dalam mengendalikan dan merencanakan kegiatan usaha dengan memberikan informasi yang dapat diandalkan dan relevan untuk pengambilan keputusan. Dari beberapa definisi diatas dapat disimpulkan bahwa Sistem Informasi Akuntansi (SIA) merupakan hal yang penting bagi perusahaan, sehingga dalam melaksanakannya diperlukan pengendalian informasi yang baik terhadap perusahaan.

Solovida (2010) menjelaskan bahwa kekurangan informasi akuntansi dalam manajemen perusahaan dapat membahayakan perusahaan kecil. Selanjutnya mereka menyatakan bahwa kondisi keuangan yang memburuk dan kekurangan catatan akuntansi akan membatasi akses untuk memperoleh informasi yang diperlukan, sehingga akan menyebabkan kegagalan perusahaan. Faktorfaktor yang mempengaruhi penggunaan informasi akuntansi pada usaha kecil dan menengah menurut Holmes dan Nicholls (1988) dalam Fitriyah (2006) ada 4 faktor yaitu pengetahuan akuntansi, skala usaha, jenis usaha, dan pengalaman usaha.

Pengetahuan akuntansi sangat diperlukan oleh manajer atau pemilik perusahaan dalam menjalankan operasional perusahaan. Menurut Holmes dan Nicholls (1988) dalam Fitriyah (2006), jika pengetahuan manajer atau pemilik rendah, akan menyebabkan banyak perusahaan kecil dan menengah menggunakan jasa Konsultan atau Akuntan Publik dalam penyediaan informasi akuntansi. Skala usaha merupakan kemampuan perusahaan dalam mengelola usahanya dengan melihat berapa jumlah karyawan yang bekerja dan berapa besar pendapatan yang diperoleh perusahaan dalam satu periode akuntansi (Holmes dan Nicholls, 1988) dalam Fitriyah (2006). Menurut Holmes dan Nicholls (1988) dalam Fitriyah (2006) jenis usaha mempunyai efek terhadap persiapan dan penggunaan informasi akuntansi. Pengalaman dalam operasional perusahaan dan lamanya perusahaan beroperasi berdasarkan pada bisnis yang sudah dijalankan akan mengindikasikan kebutuhan akan informasi akuntansi yang sangat diperlukan (Holmes dan Nicholls, 1988) dalam Fitriyah (2006).

Di samping 4 faktor diatas, Solovida (2010) juga menambahkan 3 faktor yang mempengaruhi penggunaan dan penyiapan informasi akuntansi, yaitu masa mempimpin perusahaan, pendidikan pemilik, dan pelatihan akuntansi. Menurut Solovida (2010), pemimpin perusahaan melakukan pengelolaan operasional perusahaan akan banyak memperoleh pengalaman dari berbagai pihak baik dari luar perusahaan maupun dari dalam perusahaan. Pengalaman manajer dalam mengelola perusahaan akan terus bertambah seiring dengan masa jabatannya memimpin perusahaan. Kemampuan dan keahlian pemilik atau manajer perusahaan ini sangatmempengaruhipenyiapan dan penggunaan informasi akuntansi. Kemampuan dan keahlian pemilik atau manajer perusahaan kecil dan menengah ini sangat ditentukan dari pendidikan formal yang pernah ditempuh. Pelatihan akan menghasilkan peningkatan profesionalisme dan eksploitasi yang lebih jauh dalam manajemen. Menurut Holmes dan Nicholls (1988, 1989) dalam Solovida (2010), pelatihan berhubungan positif terhadap sejauhmana penyediaan informasi akuntansi untuk membuat keputusan dalam perusahaan kecil. 
(M)

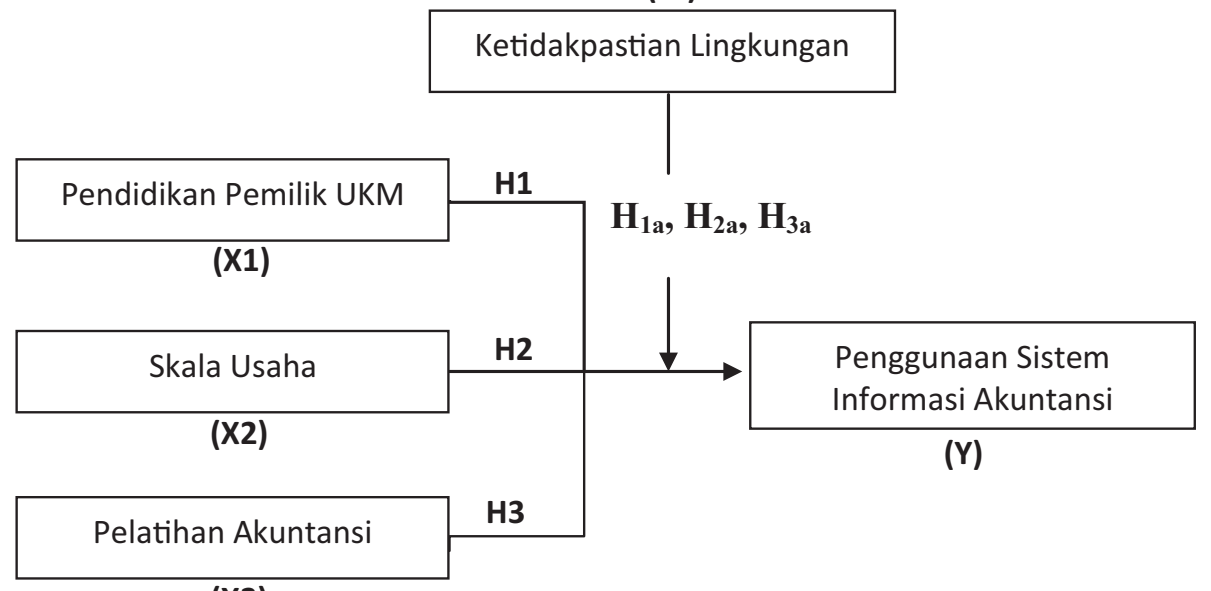

(X3)

\section{Gambar 1: Model penelitian}

Kemampuan dan keahlian pemilik atau manajer perusahaan kecil dan menengah ini sangat ditentukan dari pendidikan formal yang pernah ditempuh (Solovida, 2010). Firmansyah (2014) menyatakan bahwa latar belakang pendidikan pemilik atau manajer berpengaruh positif dengan pengguna sistem informasi akuntansi pada usaha kecil dan menengah di Kota Malang. Kemampuan dan keahlian pemilik atau manajer perusahaan ini sangat mempengaruhi penyiapan dan penggunaan informasi akuntansi. Rahman (2016), pendidikan manajer berpengaruh terhadap penggunaan sistem informasi akuntansi pada BMT se-karesidenan Pati semakin tinggi pendidikan formal yang pernah diikuti manajer, maka akan semakin meningkatkan motivasi manajer menggunakan sistem informasi akuntansi.

Semakin tinggi tingkat pendidikan pemiliki usaha maka akan semakin cepat dalam memprediksi kondisi lingkungan eksternal yang dapat mempengaruhi operasional usahanya. Adanya ketidakpastian lingkungan yang tinggi dengan pendidikan pemilik usaha yang tinggi maka diperlukan sistem informasi akuntansi untuk menanggulangi kompleksitas dari lingkungan. Pendidikan dirasa penting bagi pemilik usaha karena merupakan faktor yang berguna dalam memecahkan masalah yang dihadapi. Kemampuan dan keahlian pemilik usaha sangat ditentukan oleh pendidikan formal yang ditempuh. Tingkat pendidikan formal yang rendah menyebabkan pemilik usaha akan rendah pula dalam penyiapan dan penggunaan sistem informasi akuntansi dibandingkan dengan tingkat pendidikan formal yang tinggi. Ini disebabkan materi pengajaran akuntansi lebih tinggi diberikan di perguruan tinggi dibandingkan dengan pendidikan yang rendah. Dari uraian di atas hipotesis yang diajukan adalah :

H1 : Pendidikan pemilik UKM berpengaruh positif terhadap penggunaan sistem informasi akuntansi pada usaha kecil dan menengah

H1a: Ketidakpastian lingkungan memoderasi pengaruh pendidikan pemilik UKM terhadap penggunaan sistem informasi akuntansi pada usaha kecil dan menengah

Sitoresmi (2013) juga menyatakan bahwa terdapat pengaruh positif antara variable dummy skala usaha dengan penggunaan informasi akuntansi pada usaha kecil dan menengah. Sedangkan menurut Firmansyah (2014), skala usaha berpengaruh positif dengan pengguna sistem informasi akuntansi pada usaha kecil dan menengah di Kota Malang. Hadi (2016) mengemukakan bahwa skala usaha berpengaruh terhadap penggunaan informasi akuntansi pada UMKM di Kabupaten Sragen. 
Adanya ketidakpastian lingkungan yang dirasakan tinggi, dengan jumlah tenaga kerja yang besar maka diperlukan informasi yang relevan untuk meningkatkan kinerja, karena informasi yang relevan tersebut dapat memberikan pilihan efektif terhadap tindakan yang dibutuhkan, yaitu penggunaan sistem informasi akuntansi. Perjalanan usaha diharapkan akan terus berkembang yang akan berakibat pada skala usaha, termasuk juga jumlah tenaga kerja yang terus meningkat jumlahnya. Hal ini disebabkan oleh kemajuan usaha yang membutuhkan jumlah tenaga kerja yang lebih besar, seiring dengan penambahan aktivitas usaha. Penambahan tenaga kerja pada usaha kecil dan menengah tidak dapat dielakkan jika terjadi perubahan aktivitas dalam usaha, berbeda dengan usaha yang mempunyai modal besar yang telah menggunakan sistem informasi dalam aktivitas usahanya. Dari uraian di atas hipotesis yang diajukan adalah :

H2: Skala usaha berpengaruh positif terhadap penggunaan sistem informasi akuntansi pada usaha kecil dan menengah

H2a: Ketidakpastian lingkungan memoderasi pengaruh skala usaha terhadap penggunaan sistem informasi akuntansi pada usaha kecil dan menengah

Menurut Solovida (2010), pelatihan akan menghasilkan peningkatan profesionalisme dan eksploitasi yang lebih jauh dalam manajemen. Pelatihan berhubungan positif terhadap sejauhmana penyediaan informasi akuntansi untuk membuat keputusan dalam perusahaan kecil. Hasil penelitian Sitoresmi (2013), menemukan bahwa semakin sering pemilik atau manajer mengikuti pelatihan formal akuntansi maka akan menyebabkan peningkatan penggunaan informasi akuntansi pada KUB Sido Rukun Semarang. Pelatihan tentang akuntansi akan sangat menentukan seberapa baik kemampuan seorang pemilik terhadap penguasaan teknis akuntansi. Rahman (2016), mengikuti pelatihan akuntansi akan membuka wawasan tentang pentingnya informasi untuk pengambilan keputusan dalam mengelola usaha, di samping itu tentunya memberikan keterampilan teknis untuk pencatatan dan penyajian informasi akuntansi.

Dengan adanya pelatihan akuntansi akan berdampak pada profesionalisme dalam manajemen. Pemilik usaha yang sering mengikuti pelatihan akuntansi dan mengalami ketidakpastian lingkungan akan membutuhkan sistem informasi akuntansi untuk mengatasi perubahan-perubahan yang terjadi di lingkungan usahanya. Pemilik usaha yang tidak mendapatkan pelatihan akuntansi, mayoritas menggunakan informasi akuntansi secara lebih intensif dibandingkan pemilik usaha yang mendapatkan pelatihan akuntansi. Hal ini disebabkan karena pengetahuan akuntansi kemungkinan bukan hanya didapatkan dari pelatihan akuntansi yang diikuti saja, namun dapat pula didapat dari pendidikan yang ditempuh, pengalaman operasional usaha maupun pengalaman pemilik usaha. Berbeda dengan pemilik UKM yang mendapatkan pelatihan akuntansi, pemilik usaha yang tidak mendapatkan pelatihan akuntansi lebih menggunakan informasi akuntansi secara lebih intensif. Meskipun tidak mendapatkan pelatihan akuntansi, pemilik usaha tersebut juga telah mendapatkan pengetahuan akuntansi pada pendidikan formal, sehingga pemilik usaha ini telah memahami dasar-dasar akuntansi. Dari uraian di atas hipotesis yang diajukan adalah :

H3: Pelatihan akuntansi berpengaruh positif terhadap penggunaan sistem informasi akuntansi pada usaha kecil dan menengah

H3a: Ketidakpastian lingkungan tidak memoderasi pengaruh pelatihan akuntansi terhadap penggunaan sistem informasi akuntansi pada usaha kecil dan menengah

\section{Metode Penelitian}

Populasi dalam penelitian ini adalah Usaha Kecil dan Menengah (UKM) Se-Jabodetabek yang terdaftar pada Kementerian Koperasi 
dan UKM tahun 2014 sampai dengan 2015. Berdasarkan rumus slovin dapat dihitung sampel dari populasi usaha kecil sebanyak 27 responden dan usaha menengah sebanyak 108 responden dengan tarif kesalahan 5\%, maka jumlah sampel yang didapat sebanyak 101 sampel. Penelitian ini menggunakan teknik sampel yaitu stratified random sampling sedangkan metode pengambilan sampel menggunakan simple random sampling, dikarenakan pemilik UKM Se-Jabodetabek memiliki peluang yang sama untuk dipilih menjadi sampel. Uji kualitas data menggunakan uji validitas dan reliabilitas. Uji asumsi klasik terdiri dari uji multikolinearitas, uji multikolinearitas uji normalitas, dan uji heteroskedastisitas dilakukan untuk memenuhi syarat best linier unbiased dan estimated. Pengujian hipotesis dilakukan dengan uji regresi moderasi. Pengujian moderasi dilakukan menginteraksikan dengan cara perkalian variabel independen dengan variabel pemoderasi.

\section{Hasil dan Pembahasan}

Profil responden terbentuk dari hasil tabulasi data yang dikumpulkan dan disusun menjadi data yang lebih terstruktur. Dari 101 responden yang berpartisipasi untuk variabel pendidikan pemilik UKM, responden dengan pendidikan terbanyak adalah S1 sebanyak 67 responden $(66,34 \%)$, diikuti SMA/K sebanyak 14 responden $(13,86 \%)$, Lainnya sebanyak 11 responden $(10,89 \%)$, dan paling sedikit berpendidikan Diploma yaitu 9 responden $(8,91 \%)$. Ditinjau dari skala usaha terbanyak adalah skala usaha kecil sebanyak 20 responden $(20 \%)$ dan skala usaha menengah sebanyak 81 responden $(80 \%)$.

Uji validitas sebanyak 101 responden yang dilakukan dengan menggunakan teknik corrected item total correlation. Dari output dapat diketahui nilai $r_{\text {hitung }}$, nilai ini kemudian dibandingkan dengan $r_{\text {tabel }}, r_{\text {tabel }}$ dicari pada signifikansi 0,05 dengan uji dua arah. Sehingga dapat disimpulkan pada variabel pendidikan pemilik UKM, skala usaha, pelatihan akuntansi, dan penggunaan sistem informasi akuntansi adalah berstatus valid. Kriteria pengujian dilakukan dengan menggunakan pengujian Cronbach Alpha ( $\alpha$ ). Suatu variabel dikatakan reliable jika memberikan nilai Cronbach Alpha> 0,60 . Hasil uji reliabilitas pada penelitian ini adalah sangat tinggi karena nilai Cronbach's Alpha rata-rata diatas 0,60 .

Model regresi akan lebih tepat digunakan dan menghasilkan perhitungan yang lebih akurat, apabila beberapa asumsi berikut dapat terpenuhi. Uji asumsi klasik ini meliputi uji normalitas, uji multikolinearitas, dan uji heteroskedastisitas. Apabila data tidak terdistribusi normal dan mengandung heteroskedastisitas maka perlu adanya perbaikan model regresi dengan cara mentransformasi data.

Uji normalitas dilakukan dengan tujuan untuk menguji apakah dalam model regresi, variabel pengganggu atau residual memiliki distribusi normal atau tidak. Distribusi atau penyebaran data dikatakan normal jika hasil uji Kolmogorov-Smirnov (Asymp.Sig (2-tailed)) tersebut diatas $5 \%$ atau 0,05 . Berdasarkan hasil penelitian menunjukkan nilai KolmogorovSmirnov sebesar 1,309 dengan signifikansi 0,065 . Berdasarkan hal tersebut maka dapat disimpulkan bahwa data terdistribusi normal.

Uji multikolinearitas dilakukan dengan melihat nilai tolerance dan variance inflation factor. Model regresi dikatakan bebas multikolinearitas jika nilai variance inflation factor $(\mathrm{VIF}) \leq 10$ dan nilai tolerance $\geq 0,10$. Dari hasil penelitian menunjukkan bahwa pendidikan pemilik UKM, skala usaha, dan pelatihan akuntansi tidak memiliki multikolinearitas.

Uji heteroskedastisitas dilakukan untuk melihat dalam model regresi terjadi ketidaksamaan variance dari residual satu pengamatan ke pengamatan lain. Asumsi yang harus dipenuhi adalah varians dari residual satu pengamatan ke pengamatan lain tidak memiliki pola tertentu. Berdasarkan hasil penelitian menunjukkan bahwa titik-titik menyebar secara acak serta tersebar baik diatas maupun dibawah angka 0 
pada sumbu Y. Hal ini berarti bahwa tidak terjadi heteroskedastisitas pada model regresi.

Hasil perhitungan nilai Adjusted $R$ Square menunjukkan bahwa pengaruh variabel pendidikan pemilik UKM, skala usaha, dan pelatihan akuntansi terhadap penggunaan sistem informasi akuntansi (SIA) dimoderasi oleh ketidakpastian lingkungan dapat diterangkan oleh model persamaan ini adalah $57,7 \%$ dan selebihnya dipengaruhi oleh faktor-faktor lain yang tidak dimasukkan dalam model regresi.
Hasil analisis regresi diketahui tingkat signifikan 0,000 . Hal ini dibuktikan dari nilai $\mathrm{F}_{\text {hitung }}$ sebesar 46,546 sedangkan $\mathrm{F}_{\text {tabel }}$ sebesar 2,69 sehingga $F_{\text {hitung }}>F_{\text {tabel }}$ dan probabilitas jauh lebih kecil dari 0,05 maka dapat menyatakan ketidakpastian lingkungan memoderasi pengaruh pendidikan pemilik UKM, skala usaha, dan pelatihan akuntansi secara serentak berpengaruh terhadap penggunaan sistem informasi akuntansi.

Table 1. Hasil Uji Moderated Regression

Analysis (MRA)

\begin{tabular}{lrrrr}
\hline Variabel & \multicolumn{1}{c}{ B } & Std. Error & \multicolumn{1}{c}{ Beta } & Sig \\
\hline Constant) &,- 782 & 1,438 & &, 588 \\
Pendidikan Pemilik UKM &,- 277 &, 205 &,- 397 &, 181 \\
Skala Usaha &, 644 &, 325 &, 708 &, 050 \\
Pelatihan Akuntansi &, 786 &, 285 &, 843 &, 007 \\
Ketidakpastian Lingkungan &, 550 &, 496 &, 674 &, 271 \\
Mod_1 $\left(\mathrm{X}_{1}^{*} \mathrm{M}\right)$ &, 109 &, 069 &, 538 &, 116 \\
Mod_2 $\left(\mathrm{X}_{2}^{*} \mathrm{M}\right)$ &,- 240 &, 104 &,- 936 &, 024 \\
Mod_3 $\left(\mathrm{X}_{3}^{*} \mathrm{M}\right)$ &,- 059 &, 098 &,- 291 &, 552 \\
\hline
\end{tabular}

Hasil penelitian ini mendukung penelitian yang dilakukan oleh Hariyadi (2013), Hadi (2016) yang menyimpulkan bahwa pendidikan pemilik UKM tidak berpengaruh signifikan terhadap penggunaan sistem informasi akuntansi pada usaha kecil dan menengah. Ketidakpastian lingkungan tidak memoderasi pengaruh pendidikan pemilik UKM terhadap penggunaan informasi akuntansi pada usaha kecil dan menengah. (Sitoresmi dan Fuad, 2013). Hasil ini membuktikan bahwa semakin tinggi tingkat pendidikan pemilik UKM tidak dapat mempengaruhi penggunaan sistem informasi akuntansi sedangkan dengan adanya ketidakpastian lingkungan maka tidak mempengaruhi minat para pemilik UKM untuk menggunakan sistem informasi akuntansi.

Penelitian ini tidak mendukung penelitian yang dilakukan oleh Solovida (2010), Firmansyah (2014), dan Rahman (2016) yang menyimpulkan bahwa pendidikan pemilik UKM berpengaruh signifikan terhadap penggunaan sistem informasi akuntansi pada usaha kecil dan menengah. Ketidakpastian lingkungan memoderasi pengaruh pendidikan pemilik UKM terhadap penggunaan informasi akuntansi pada usaha kecil dan menengah. (Setyaningrum, Wiratno, dan Sukirman, 2014)

Hasil kesimpulan penelitian ini sejalan dengan penelitian Firmansyah (2014), Hadi (2016), dan Rahman (2016) yang mengemukakan bahwa skala usaha berpengaruh signifikan terhadap penggunaan informasi akuntansi keuangan. Ketidakpastian lingkungan memoderasi pengaruh skala usaha terhadap penggunaan SIA pada usaha kecil dan menengah. (Setyaningrum, Wiratno, dan Sukirman, 2014). Hasil ini membuktikan bahwa semakin tinggi skala usaha serta adanya ketidakpastian lingkungan maka suatu usaha 
untuk menggunakan sistem informasi akuntansi semakin tinggi dan tidak dapat dielakkan jika terjadi perubahan aktivitas dalam usaha, berbeda dengan usaha yang mempunyai modal besar yang telah menggunakan sistem informasi dalam aktivitas usahanya.

Hasil penelitian ini mendukung penelitian yang dilakukan oleh Solovida (2010), Sitoresmi (2013), dan Rahman (2016) yang menyimpulkan bahwa pelatihan akuntansi berpengaruh signifikan terhadap penggunaan SIA pada usaha kecil dan menengah. Ketidakpastian lingkungan memoderasi pengaruh pelatihan akuntansi terhadap penggunaan SIA pada usaha kecil dan menengah. (Setyaningrum, Wiratno, dan Sukirman 2014).

\section{Kesimpulan, Keterbatasan, dan Saran}

Pendidikan pemilik UKM berpengaruh signifikan terhadap penggunaan sistem informasi akuntansi pada usaha kecil dan menengah SeJabodetabek. Begitu pula ketika dimoderasi oleh ketidakpastian lingkungan, pendidikan pemilik UKM berpengaruh signifikan terhadap penggunaan sistem informasi akuntansi pada usaha kecil dan menengah Se-Jabodetabek. Hal ini berarti jika semakin tinggi pendidikan formal pemilik UKM maka pemilik usaha semakin termotivasi untuk menggunakan sistem informasi akuntansi dalam mengambil suatu keputusan.

Skala usaha memiliki pengaruh signifikan terhadap penggunaan sistem informasi akuntansi pada usaha kecil dan menengah Se-Jabodetabek. Begitu pula ketika dimoderasi oleh ketidakpastian lingkungan, skala usaha mempunyai pengaruh signifikan terhadap penggunaan sistem informasi akuntansi pada usaha kecil dan menengah Se-Jabodetabek. Pelatihan akuntansi tidak berpengaruh signifikan terhadap penggunaan sistem informasi akuntansi pada usaha kecil dan menengah Se-Jabodetabek. Sedangkan ketika dimoderasi oleh ketidakpastian lingkungan, pelatihan akuntansi tidak berpengaruh signifikan terhadap penggunaan sistem informasi akuntansi pada usaha kecil dan menengah Se-Jabodetabek. Hal ini berarti dengan mengikuti pelatihan akuntansi akan membuka wawasan tentang pentingnya informasi untuk pengambilan keputusan dalam mengelola usaha, disamping itu tentukan memberikan keterampilan teknis untuk pencatatan dan penyajian informasi akuntansi.

Keterbatasan penelitian ini bahwa variabel yang digunakan untuk menguji penggunaan sistem informasi akuntansi pada penelitian ini hanya terbatas pengaruh pendidikan pemilik UKM, skala usaha, dan pelatihan akuntansi. Masih banyak faktor lain yang dapat mempengaruhi penggunaan sistem informasi akuntansi seperti jenis usaha dan pengalaman usaha. Riset hanya menggunakan kuesioner dengan media online, sehingga ada kemungkinan seperti jawaban tidak serius, responden menjawab asal serta pertanyaan yang kurang detail atau dipahami oleh responden. Penelitian ini hanya dilakukan pada Usaha Kecil dan Menengah Se-Jabodetabek yang terdaftar pada Kementerian Koperasi dan UKM, sehingga hasil penelitian belum dapat digeneralisir pada kabupaten maupun kota.

Peningkatan pengetahuan akuntansi pemilik usaha kecil dan menengah sangat diperlukan untuk mengelola usahanya. Oleh karena itu, bagi pihak-pihak yang terkait dengan pengembangan dan pemberdayaan usaha kecil dan menengah Se-Jabodetabek, terutama Dinas Koperasi dan Usaha Kecil dan Menengah (UKM) Se-Jabodetabek diharapkan dapat memberikan pelatihan maupun pengarahan mengenai akuntansi kepada pemilik usaha kecil dan menengah. Ikatan Akuntan Indonesia (IAI) perlu menyusun standar akuntansi khusus bagi Usaha Kecil dan Menengah (UKM), karena standar akuntansi yang umum digunakan sekarang terlalu memberatkan (overload) bagi Usaha Kecil dan Menengah (UKM). Selain itu, Ikatan Akuntan Indonesia (IAI) juga perlu meningkatkan sosialisasi pencatatan akuntansi pada pemilik usaha kecil dan menengah. 


\section{Daftar Referensi}

Ajzen, I and Fishbein, M. 1980. Understanding Attitudes and Predicting Social Behavior. Englewood Cliffs, NJ: Prentice Hall.

Astuti, Era. 2007. Pengaruh Karakteristik Internal Perusahaan Terhadap Penyiapan dan Penggunaan Informasi Akuntansi Perusahaan Kecil dan Menengah di Kabupaten Kudus. Tesis. Semarang: Program PascaSarjana Magister Akuntansi Universitas Diponegoro.

Astuti, S. D., \& Widiatmoko, J. (2003). Profil Usaha Kecil Menengah UKM Jawa Tengah. Fokus Ekonomi, 2(3), 215-228.

Duncan, R. B. (1972). Characteristics of organizational environments and perceived environmental uncertainty. Administrative science quarterly, 313-327.

Edison, G., Manuere, F., Joseph, M., \& Gutu, K. (2012). Evaluation of factors influencing adoption of accounting information system by small to medium enterprises in Chinhoyi. Interdisciplinary Journal of Contemporary Research in Business, 4(6), 1126-1141.

Fitriyah, H. 2006. Analisis Faktor-faktor yang Mempengaruhi Penggunaan Informasi Akuntansi pada Usaha Menengah Kabupaten Sidoarjo. Tesis. Surabaya: Universitas Airlangga.

Ghobakhloo, M., Hong, T. S., Sabouri, M. S., \& Zulkifli, N. (2012). Strategies for successful information technology adoption in small and medium-sized enterprises. Information, 3(1), 36-67.

Govindarajan, V. (1986). Impact of participation in the budgetary process on managerial attitudes and performance: Universalistic and contingency perspectives. Decision Sciences, 17(4), 496-516.

Hadi Misbakhul. 2016. Analisis Faktorfaktor yang Mempengaruhi Penggunaan Informasi Akuntansi pada UMKM di Kabupaten Sragen. Skripsi. Surakarta:
Fakultas Ekonomi dan Bisnis Universitas Muhammadiyah.

Hariyadi. 2013. Faktor-faktor yang Mempengaruhi Penggunaan Informasi Akuntansi pada Usaha Mikro, Kecil dan Menengah (UMKM) yang Bergerak di Bidang Jenis Usaha Makanan di Kota Tanjung Pinang. Skripsi. Semarang: Fakultas Ekonomi Program Studi Akuntansi Universitas Diponegoro.

Holmes, S., \& Nicholls, D. (1989). Modelling the accounting information requirements of small businesses. Accounting and Business Research, 19(74), 143-150.

Ismail, N. A., \& King, M. (2014). Factors influencing the alignment of accounting information systems in small and medium sized Malaysian manufacturing firms. Journal of Information Systems and Small Business, 1(1-2), 1-20.

Ismail, N. A., \& King, M. (2014). Factors influencing the alignment of accounting information systems in small and medium sized Malaysian manufacturing firms. Journal of Information Systems and Small Business, 1(1-2), 1-20.

Kasdi, A. (2016). Skala Usaha Dan Pelatihan Akuntansi Syariah Terhadap Penggunaan Sistem Informasi Akuntansi Di Bmt Se-Karesidenan Pati. Equilibrium Pascasarjana Stain Kudus, 4(1).

Kuncoro, M. (2008). Tujuh tantangan UKM di tengah krisis global. Harian Bisnis Indonesia, 21.

Milliken, F. J. (1987). Three types of perceived uncertainty about the environment: State, effect, and response uncertainty. Academy of Management review, 12(1), 133-143.

Rahutami, A. I. (2009). Kekuatan Lokal Sebagai Roh Pembangunan Jawa Tengah: Sumbang Pikir Universitas Katolik Soegijapranata.

Romney and Steinbart. 2010. Accounting Information Systems. Edisi 8. Jakarta: GRAMEDIA. 
Setyaningrum, Wiratno, dan Sukirman. 2014. Pengaruh Pendidikan Pemilik, Pengetahuan Akuntansi Pemilik, Budaya Perusahaan, dan Umur Usaha terhadap Penggunaan Informasi Akuntansi pada UKM dengan Ketidakpastian Lingkungan sebagai Variabel Pemoderasi (Studi Empiris terhadap UKM yang Menghasilkan Produk Unggulan di Kabupaten Banyumas). Skripsi. Purwokerto: Universitas Jenderal Soedirman.

Solovida, G. T. (2010). Faktor-Faktor yang Mempengaruhi Penyiapan dan Penggunaan Informasi Akuntansi Pada Perusahaan Kecil dan Menengah Di Jawa Tengah. PRESTASI, 6(01).

Spilker, B. C. (1995). The effects of time pressure and knowledge on key word selection behavior in tax research. Accounting Review, 49-70.
Trianti, Yunik. 2013. Pengaruh Strategi Bauran Pemasaran Terhadap Volume Penjualan dan Profitabilitas (Survei pada Distro di Plaza Parahyangan Bandung). Skripsi. Bandung: Universitas Pendidikan Indonesia.

Urquía Grande, E., Pérez Estébanez, R., \& Muñoz Colomina, C. (2011). The impact of Accounting Information Systems (AIS) on performance measures: empirical evidence in Spanish SMEs.

Widiyanti, Yayuk. 2013. Analisis Faktor-faktor yang Mempengaruhi Persepsi Pengusaha Kecil dan Menengah atas Penggunaan Informasi Akuntansi Keuangan (Studi pad aPengusaha Kecil dan Menengah di Sentra Kerajinan Tas Kain Kabupaten Kendal). Skripsi. Semarang: Jurusan Akuntansi Fakultas Ekonomi Universitas Negeri Semarang. 